\title{
Extensive Reading And Dictionaries: An Approach to vocabulary acquisition to meet contextual requirements for Advanced English Language Learners
}

\author{
By: \\ Fitri Rizki, Jalaluddin \\ Lecturer of STIKOM Tunas Bangsa Pematangsiantar \\ fitri_rizki@stikomtb.ac.id
}

\begin{abstract}
Abstrak. Pemahaman penuh atas pesan yg dsampaikan melalui bhsa inggris lisan atau tulisan akan menghemat byk wktu pembaca dan jg pndngar untuk memahami informasi yg dsampaikan. Pnggunaan kata yg tepat yg mewakili apa yg dmiliki penulis atau pembicara ddlm pikirannya berpotensi membantu pmbaca dan pndengar untuk memahami pesan dlm waktu yg sesingkat" nya. Dengan perbendaharaan yg representatif yg sesuai dgn kebutuhan konteksnya akan menjamin pesan itu sampai kpda objek yg diinginkan. Penggunaan kata yg tepat akan mnciptakan pesan yg benar" memiliki makna bagi pembaca dan pndengar. Dengan mmbaca secara ekstensif dan menggunakan kamus monolingual, seorang pelajar akan mndapatkan penguasaan perbendaharaan kata.
\end{abstract}

Abstract. Fully understanding the message delivered in written English or Spoken English will save a lot of time for the readers as well as the lisnters to have the comprehension of the information conveyed..The use of appropriate words that represent what the writer or the speaker has in his mind has the potential to enable the readers or the listeners to take the required messages in the shortest possible time. With representivve vocabulary that are used to meet contextual requirements will guarantee a message to reach its required object. Correct use of words will create fully meaningful messages to their readers as well as listeners. By extensive reading and use of monolingual dictionaries, a learner will gain the vocabulary acquisition

Keywords: written English, contextual requirement, appropriate words, vocabulary acquisition. 


\section{INTRODUCTION}

A man is a social being who lives in a community and in the process he has to live and communicate with others. He has a lot of things that he needs from others, he has a lot that force him to hear or to listen to others. And simultenously, he has a lot that he has to tell others. To make each of what he needs run as he requires, he needs to speak with others, for which he needs a means of communication - a language, and in this article, the writer is interested in English Language.

If one is ambitious to successfully use English as a foreign language, he has to make sure that he has a good command of the Language It is not only grammar that one should master but vocabulary knowledge also plays very important role. There are excellent reasons that exist why learners have to pay full attention to vocabulary knowledge. If a learner has a good mastery of grammar but he is poor in vocabulary, he will break down in having a communication.. A large vocabulary is essential for mastery of a language. Second, langage acquirers know this. Therefore, on the theoretical level, the study of the acquisition of vocabulary knowledge can help learners understand a language. (Krashen, 2009).

Then, a new problem is emerging. When one is writing, the vocabulary that he uses in his language does not represent the fact hat the readers have to know or to identify. The words he expresses do not clearly inform the required data. For instance : "After finding dynamite, Swedish-born Alfred Nobel became a very rich man." The word "finding" in the statement means discovering something unexpectedly or by chance (Hornby,2010). Alfred Nobel did not find dynamite by chance; he was the first person to make the explosive available on earth and for this reason, the writer of the statement should have used "inventing" which means "producing or designing something that has not existed before" instead of "finding". So, it can be imagined that the readers of the first statement may think that the Swedish-born man was not the first person to make the dynamite existed on earth. And later he may ask "Who was the first ?" And fantastically, a case of this kind keeps being carried out even by some newly graduated Masters majoring in English in Indonesia. And even worse, they have not realized to have made the mistakes in the use of words to meet contextual requirement.

Speakers especially writers have to make sure about the message they should obtain from what they read or hear and they have to be concerned about conveying his own messages across to others. With representive words, readers will find pleasure in listening to jokes. A communication will run smoothly if the speakers are very careful about the choice of words. If they use the words that are appropriate to the requirement, the sentences they express will be well 
comprehended by the listeners or the readers. So the choice of words creates a dinamic way for the readers and the listeners to discover what the message is about. Not a man wants his listeners and his readers find his message vague or ambiguous. Nobody wants to go around a city and spends hours just to find out what he needs to have. Failure in the use of appropriate words will affect the readers.. Writers and speakers, therefore, keep improving the vocabulary they use in their language just to satisfy their listeners and readers. This fact reveals that the choice of words or the vocabulary that one uses in his language plays very important role in making sure that the message he is delivering is understood. This reality proves that the choice of words is significantly inportant not only for individual person but also for commercial organizations that spend a lot of effort and money on finding specific names for their products, specific words for their slogans and on creating messages that will meet with the comprehension of the customers as well as the prospective buyers (Kreidler, 2002: 1). Once the words used in the message are vague, prospective buyers may misunderstand the information about the products and this will lead to customers' disappointment that must be avoided by the manufacturers as much as possible. The fact forces the writer to ask two questions that later leads to the finding of limitation of the problem.

1. What approach will suit the learners to apply in order to achieve the mastery of

contextual vocabulary kn owledge

2. How will the approach be applied in order to make sure that the mastery of contextual vocabulary knowledge can surely be achieved.

\section{REVIEW OF LITERATURE}

Reading is an action of looking at and understanding the meaning of written or printed words or symbols (Hornby, 2010). For information, people have to read and to listen. But in this study, the writer deals only with reading; printed or electronic materials. And the development of technology has brought effect to the ways information is presented to the readers: there is an ongoing transition of reading from print to screen and the book is challenged by an increasing number of digital reading devices like computers and laptops, e-books, tablet devices and smart-phones. The paradigm of reading, especially for young readers, is increasingly screen-based rather than paper-bound (Mangen et al, 2012). But whatever means they have, when reading, they must be confronted with unfamiliar words, for the meaning of which they need a dictionary, printed or electronic. 


\section{Dictionaries}

Dictionaries are of two types: monolingual and bilingual. A monolingual dictionary provides the mening of a word in the form of definition. It provides more in-depth explanation pertaining to the function of a word in context (Albus et al, 2005) and thus the learner, with the knowledge of the word definition, has the potential to find out the contextual meaning of an unfamiliar word and also to use it in his own senteces when he writes while a bilingual dictionary supplies meaning in an accessible fashion. It tends to lead student to depend on one-to-one correspondence of words between the meaning of an unknown word in the second language and translation in their first language (Baxter, 1980; Nation, 2001)

\section{Approach}

The word approach which, in this paper, serves as a noun may lexically mean a way of dealing with somebody or something, or a way of doing or thinking about something such as a problem or a task (Hornby, 2010), but it may mean diffenrent things depending on the context in which that word is used.

An approach plays a critically important role in achieving target of teaching objective. The teacher has to be very selective in the use of an approach. An approach will serve as a bridge that will definitely leads a person to his destination. Due to the fact, there must be a conscistency of teaching approach. Concistency implemented by teachers is one of the 12 key factors to be carried out for the promotion of a school effectiveness (Mortimore, 1988). So, if all the teachers in a school can be led into using the guideliness in the same manner, a uniformity in the way of delivering the teaching materials, the impact of the teaching process on students' progress will be positive ( Chitty, 1997). It has been very clear that the implementaton of an appropriate approach for the attaintment of a teaching objective has to be the priority.

Emdin (2014), in his first year of teaching, was given straight-forward instructions for what he was charged to do. He was told to comply with the curriculum and had to make sure that his students did not disrupt the classroom. The state standards had to be achieved with the purpose that the learners passed the year-end standardized examinations follwed by some other series of things he had to do. Even some assignments had already ornamented the margins to be given to the students. The parents were called just to inform them of their children's inappropriate behaviour. The whole instructions were so structured that he was forced to ignore students who were asking brilliant questions. These students immediately went frustrated and disengaged and finally became disconnected. This poor atmosphere led to disinterest and behaviour problems. 
Teaching process became a battle to stick to the curriculum and a constant fight against students who no longer liked school. And these series of things have been the reasons why Emdin decribed five approaches to teaching, successfully giving motivation to the students and the teachers in learning and teaching process in many school across the country.

Kim (2005) in his research suggested that a school need an approach to pursue the academic achievement, self- concept and learning strategies. He, then, conducted a study on constructivist approach in comparison with traditional approach, through which he concluded that the students preferred constructivist environment to a traditional classroom. Driessen \& Sleegers (2000) even emphasized that there must be a consistency of teaching approach to reach students' achievement. In the literature of school effectiveness, consistency of teaching approach is a regularly recurring notion. Mortimore (1988) confirmed that consistency among teachers is one of the twelve key factors in the promotion of school effectiveness. Creemers (1994a, 1994b) suggested that, at the class level, there be a need for an integrated teaching approach and an introduction of consistency principle. When elements of effective teaching behaviour, teaching materials and group composition are combined and coordinated,, a synergic effect will emerge and each element will surely support each other to reach the teaching objectives.

\section{Vocabulary Acquisition}

Vocabulary can be defined as ' words to be used for effective communication; words in speaking (expressive vocabulary) and words in listening (receptive vocabulary)" (Neuman \& Dwyer, 2009, p. 385).

When one begins to learn a foreign language, the first problem he will have is vocabulary accquisition, without which a leaner will fail to let others know what he has in his mind and thus a communication will be blocked. When a transfer of information is taking place, a language with its vocabulary is going into its function, because there is very close relationship between both a language and vocabulary knowledge and due to the fact it is found out that with the knowledge of vocabulary a language can be used. (Nation, 2001). The more vocabulary a learner has the more succesful a communication will run. Schmitt (2000:55) emphasizes that lexical knowledge is the heart of communicative comptence and the second language acquisition. Laufer and Nation (1999), Maximo (2000), Read (2000), Gu (2003), Teller (2008) and Nation (2011) realize that vocabulary acquisition in learners effort to have the mastery of English as a second language and also of English as a foreign language plays a key role. With 
sufficient vocabulary knowledge, the speakers as well as the writers will smoothly inform others what is required by both parties. And finally they will be satisfied with the information they share and this atmosphere will lead to the comprehension about what to do and thus business runs as expected.

\section{Context}

Hornby (2010) defines that the word context means: (1) words that come before or after a word, phrase, statement, etc., helping to show what its meaning is, (2) circumstances in which, he will surely confronted with several unfamilar words for which he has to do his best to find something happens or in which something is to be considered. If the learner neglects new words, he will fail to comprehend the message containing in the text. For a solution

\section{METHODS}

\section{Extensive Reading and Using Dictionaries}

Researchers Agree that in one's effort to have the mastery of a second language, one has to devote his time in vocabulary learning. Due to the fact, a learner keeps working to find the best means of enriching his vocabulary although de Groot (2006) says that it is still not clear because it depends on a wide variety of factors. Students who engage in wide reading develop extensive vocabularies (Nagy \& Anderson, 1984). It is quite natural; the more a learner reads, the more unfamiliar words he will be confronted with and the more contextual vocabulary he will glean through the use of dictionary that he has. Good readers are active readers, they have clear goal in mind for their reading, they constantly evaluate whether the text and their reading of it is meeting their goal, they read selectively, continually making decisions about their reading: what to read carefully, what to read quickly, what not to read, what to reread and so on. They construct, revise and question the meaning as they read (Duke \& Pearso, 2002). If the goal is to glean as many contextual vocabulary as possible, good readers are very much selective in their reading texts that meet with the context they require and this behaviour will lead them to being very experinced readers and finally will be adequately strong with the knowledge of contextual vocabulary. The experience and the knowledge will facilitate their writing activity to meet the contextual requirement of what they write.

The use of a dictionary positively affects incidental vocabulary learning. In the Knight (1994) study, American students of Spanish who had read Spanish texts while using a dictionary later remembered more word meanings than those who had had no dictionary at their disposal. 
When a learner runs into a new word in a text, he will have a couple of strategies to find the meaning: asking a friend or a teacher, using a dictionary or parsing the meaning from the context (Harley \& Hart, 2000; Qian, 2004) although using a dictionary or guessing are the most preferable. When a learner is reading a text, and he has insufficient time to consult his dictionary, he will adopt the most eficient strategy: guessing. One may guess the meaning by learning the context and this is essential in second language learning but the outcome of this strategy is not always accurate thus Kaivanpanah and Alavi's (2008) confirms that learners' inferences about the meaning of unfamililar vocabulary are not always reliable. The effects of contextual guessing are detemined by the learner's knowldge of linguistics, strategies and the world (Nagy, 1995), so the learner will not be sure of the appropriate use of the words he gains through contextual guessing.

Advanced students in Indonesia, who are mostly high school students, are those having learned English for at least four years and the age brackets are around 16 to 19 . With this length of learning English, they have sufficient vocabulary to be capable of understanding the word definitions available in mono-lingual dictionaries. Their serious drawback, because of being interested only in having bilingual dictionaries, is making use of appropriate vocabulary to meet contextual requirement. For these students, to have adequate contextual vocabulary, they have to read extensively and the consequence is that they will be confronted with a lot of unfamiliar words. And for the meaning, they will have to to look up a monolingual dictionary that they have to use by instruction. Using bilingual dictionaries will give them the least

\section{RESULTS AND DISCUSSION \\ What approach is appropriate}

The national language in Indonesia is "Bahasa Indonesia" (the Indonesian Language) so the language of instruction used in all schools in Indonesia is "Bahasa Indonesia". When reading a text, a learner may find several new words for the meanings of which he can ask his mates, his teachers ' consult a dictionary or contextual guessing. The meanings of the new words should meet with the contextual requirement, and the same thing is taking place when he writes in English. The same case will certainly happens to him; the words he uses in what he writes should meet with the context. For example: a learner wants to write a sentence like: "Indonesia's is rupiah". To complete the sentence he has several nouns to choose: "money, bill or currency", which noun is to be used. For the right word, he has no other way but to find out the definition of each noun, for which he has only a single way: look up his dicttionary. Which 
dictionary is to use ? Is it bilingual, (usually bi-directional: English to first language and first language to English) or mono-lingual (English to English dictionary)? A bilingual dictionary supplies meaning in such an accessible fashion that it does not provide an access to the problem. The writer tends to use the same meaning for the three words. And in return, the learner will think that any of the three nouns can be used to complete the sentence.

Monolingual dictionary generally provides more in-depth explanations pertaining to the function of vocabulary in context (Albus et al., 2005), it requires a large amount of vocabulary and grammartical knowledge to understand the meaning of a word. Hornby says that money is (1). a means of payment, esp. coins and papernotes. (2). Wealth, the total value of somebody's property (3) payment for work (4) in plural "money or monies", a sum of money; bill means (in US) note, eg: a ten-dollar bill and currency means the system of money used in a country. Since the language above is used in spoken English, the noun"money" can be used because when the listener needs some information, the speaker is there to serve, but when the sentence is for "written English", the writer has no other choice but to use a word that is appropriate to the requirement of the context, "currency".

But the problem is that the learner does not have a choice of words just because of having lack of vocabulary, for instance : the learner wants to write: "The three terrorists have already been ........ to death by the court. So the learner has to consult his Indonesian-English dicttionary (Echols \& Shadily, 2000) which suggests three verbs to choose: punish, judge and sentence. For the appropriate verb to use, again the learner needs his monolingual dictionary from which he will have the definition of the verb including the function in context. Hornby says that "punish" means "make somebody suffer" or "cause somebody to suffer for a particular crime or wrongdoing; "judge" means "assess somebody's good and bad qualities or "to decide a case in a lawcourt" and "sentence" means "to state that somebody is to have a certain punishment. The three in-depth explanations leads the learner to a decision that the most appropriate verb to be used in his sentence is "sentence" in "The three terrorists have already been sentenced to death by the court.

Pragmatic philosopher John Dewey, in his Democracy and Education (1916), defined education as a process to restructure the individual experience by reflective thinking through expanding one's present experience. Individual experience is the core of knowledge, not knowledge offered by others. Thus, continuous development of the learner must be stimulated through his interaction to his environment to create meaningful knowledge. 
As a foreign language learner, a student has to create an English language reading world of his own. This is critically important because it will lead him to having a lot of experience in the language through which he will be confronted with a lot of new words. In response to this challenge, serious learners will look up a dictionary for the meaning. What is more is that the text a learner reads is certainly the one he is interested in, due to this fact, the reader will be very well motivated to comprehend the message in the text. Fortunately, the learner will see these unfamiliar words several times and this is positive because these words will consequently stay longer in his mind. The more unfamiliar words the reader has the more vocabulary mastery he will have. Increasing learners' volume of reading leads to measurable gains in their vocabulary knowlege and other measures of language proficency (Elley, 1991). The strongest evidence of the benefits of reading for vocabulary growth for the learners is that these learners keep encountering a higher proportion of unfamiliar words. This is a process of vocabulary learning. If he successfully does this he will be accustomed to the words which means that he will have adequate vocabulary and have the potential to use appropriate words as required by the context. Once a writer does not use the right words, the communication he is having will break down (Allen, 1983: 5). This incident vocabulary learning strategy can be applied by both high schol students and university students (Day et al, 1991).

\section{The dictionary a learner is suggested to use is monolingual}

Definition-based learning in which a learner has to depend on monolingual dictionary, typically involves memorizing (or attempting to memorize) brief definitions representing only a single meaning and thus leads to shallow level of knowledge (Graves, 1986). But this vocabulary learning strategy has its own deep advantage; filled with the in-depth explanation and the function of the words in context, the learner very well understands the meaning and the appropriate use of the words. With full comprehension of the meaning and the use of the words, the learners knows well why to use the words in a context. Bilingual dictionaries do not provide the learners in Indonesia with in-depth explanation of the unfamiliar words, and thus Indonesian learners whose mother tongue is Bahasa Indonesia find it so difficult to use appropriate words in a context. They tend to use the words as recommeded by their Indonesian-English dictionaries. The implication is that the readers do not have representative information as wanted by the writers.

\section{CONCLUSION}

1. For better knowledge of contextual vocabulary, a learner has to read extensively. 
2. For in-depth explanation of the meaning of unfamiliar words together with their functions, a learner has to use monolingual dictionaries.

3. The more extensively a learner reads, the more he will be confronted with unfamiliar words and finally the more vecabulary knowledge he will achieve.

4. Extensive reading will provide a learner with vast experience of being confronted with contextual vocabulary, and this experience will lead him to being more powerful in the use of appropriate words to meet contextual requirement

\section{REFERENCES}

Albus, D., Thurlow, M., Liu, K., \& Bielinski, J. (2005). Reading test performance of English-language learners using an English dictionary. The Journal of Educational Research, 98(4),245-254. http://dx.doi.org/10.3200/JOER.98.4.245-256, in The Use of Dictionary and Contextual Guessing Strategies for Vocabulary Learning by Advanced English-Language Learners by Shufen Huang \& Zohreh Eslami, 2013

Allen. (1983) Journal of Humanities and Social Sciences, Feng Chia University, in Current Trends of Vocabulary Teaching and Learning Strategies for EFL Settings by Wei-Wei Shen, 2003

Cameron, L. (2001). Teaching languages to young learners. Cambridge: Cambridge University Press, in The Importance of Vocabulary in Language Learning And How To Be Taught by Mofareh Alqahtani, 2015

Chitty, C. (1997). The School Effectiveness Movement: Origins, Shortcomings And Future Possibilities. The Curriculum Journal, 8, $45-62$ in Consistency of Teaching Approa-ch And Student's Achievement: An Empirical Test, 2011 by Geert Driessen \& Peter Sleegers

Creemers, B. (1994a). Effective Instruction, an Emphirical Basis For a Theory of Educational Effectiveness, in D. Reynolds et al, Advances in School Effectiveness Research and Practice (p.189-205) Oxfort: Pergamon, in Concistency of Teaching Approach and Student Achievement: An Emphirical Testm, by Greet Driessen \& Peter Sleegers.

Creemers, B. (1994b) Effective Instruction as a basis for effective education in schools, in Concistency of Teaching Approach and Student Achievement: An Emphirical Testm, by Greet Driessen \& Peter Sleegers.

Day, Richard R. Et al. (1991) Incident EFL Vocabulary Learning And Reading

Driessen,Greet \& Sleegers Peter , 2.000 Consistency of Teaching Approach and Students' Achievement: An Empirical Test

Dewey, John. (1916). Democracy and education. New York :Macmillan

De Groot, A.M.D. (2006). Effect of Stimulus Characteristics and Background Music on Foreign Language Vocabulary Learning and Forgetting, Language Teaching Research, 10(3), 463,506, in Instructed Second Language Vocabulary Learning by Nobert Schmitt, 2008 
Duke, Nell K. \& Pearso, P. David. (2002). Effective Practices For Developing Reading Comprehension, International Reading Association, Third Edition-2002

Echols, John M., \& Shadily, Hassan, 2000, Kamus Indonesia Inggris, An Indonesian-English dictionary, Third Edition, PT Gramedia, Jakarta

Elley, W. (1991). Acquiring literacy in a second language: The effect of book based programs. Language Learning 41, 375-411, in On The Role Of Context In First-And Second-Language Vocabulary Learning by William E. Nagy, 1995, University of Illinois

Emdin, Christopher. (2014). www.twitter.com/chrisemdin,

$\mathrm{Gu}, \mathrm{Y}$. (2003a). Vocabulary learning in second language: person, task, context and strategies.Electronic Journal. TESL-EJ, 7, 2, 1-26, in The Importance Of Vocabulary In Language Learning And How To Be taught by Mofareh Alqahtani (2015).

Gaskins, I. (2004). Word detectives. Educational Leadership, 61(6), 70-73. in The Use of Dictionary and Contextual Guessing Strategies for Vocabulary Learning by Advanced English-Language Learners by Shufen Huang \& Zohreh Eslami, 2013

Huckin, T., \& Haynes, M., (1993). Summery and Future Directions. In J. Coady (Eds). Second language reading and vocabulary learning (pp.289-298). Norwood, NJ:Ablex. In Incidental Vocabulary Learning by Advanced foreign Language Students :The Influence of Marginal Glosses, Dictionary Use And Reoccurance of Unknown Words by Jan H. Hulstijn; Merel Hollander and Tine Greidanus, 1996

Harley, B., \& Hart, D. (2000). Vocabulary learning in the content-oriented second language classroom:Student perceptions and proficiency. Language Awareness, 9, 78-96. http://dx.doi.org/10.1080/09658410008667139, in The Use of Dictionary and Contextual Guessing Strategies for Vocabulary Learning by Advanced English-Language Learners by Shufen Huang1 \& Zohreh Eslami2

Hornby,A.S. (2010). OXFORD Advanced Learner's Dictionary of Current English. Seventh Edition, London: The English Language Book Society And Oxford University Press

Kaivanpanah, S., \& Alavi, M. (2008) Deiring unknown word meaning fromcontect. Is it reliable ? RELC Jlurnal , 39 (I) 77http://dx.doi.org/10.1177/0033688208091141, in The Use of Dictionary and Contextual Guessing Strategies for Vocabulary Learning by Advanced English-Language Learners by Shufen Huang1 \& Zohreh Eslami2

Kim, Jong Suk. (2005). The Effect of a Constructivist Teaching Approach On Student Academic Achievement, Self-Concept and Learning Strategies, Asia Pacific Education Review, 2005, Vol.6,No. 1, 7-19

Knight, S. (1994). Dictionary: The toll of last repost in foreign language reading ? A new prospective . Modern Language Journal 78, 285-299 in Incidental Vocabulary Learning by Advanced Foreign Language Students :The Influence of Marfinal Glosses, Dictionary Use and Reoccuence Of 
Unknown Words byJan H. Hulstijn, Merel Hollander and Tine Greidanus, The Modern Language Journal, Vol 80, No. 3, 2004

Kreidler, Charles W. (2002). Introducing English Semantic, Routledge, London

Krashen, Steven, 2009, We Acquire Vocabulary And Spelling By Reading, Additional Evidence For The Input Hypothesis, Blackwell Publishing

Llach,Maria Pilar Agustin. (2009). The Effect Of Reading Onl, Reading And Comprehension, And Sentence Writing In LexicalLearning In $A$ ForeignLanguage: Some Preliminary Results, Universidad de La Rioja, Resla 22,9-33

Laufer, B.\&P. Nation. (1999). A Vocabulary Size Test Of Controlled Pruductive Ability. Language Testing 16,33-51 in The Importance Of Vocabulary In Language Learning And How To Be taught by Mofareh Alqahtani (2015).

Laufer, B. \& P. Nation. (1999). A vocabulary size test of controlled productiveability.Language Testing 16, 33-51.

Mongen, Anne et al. (2012). Reading Linear Texts On Paper Versus Computer Screen: Effect On Reading Comprehension, International Journal Of Educational Research 58 (2013) 61 - 68

Motimore, et al. (1988). Shool Matters. The Jumior Years: Well. Open Books, in Consistency of Teaching Approach And Student's Achievement: An Empirical Test, 2011 by Geert Driessen \& Peter Sleegers

Mortimore, M., et al. (1998). School Matters, The Junior Years, Wells: Open Books. in The Importance Of Vocabulary In Language Learning And How To Be taught by Mofareh Alqahtani, 2015.

Maximo, R. (2000). Effects if Rote, Context, Keyword and Context Keyword Method on Retentio Of Vocabulary in EFL Classroom, Language Learning, 50, 2, 385-412 in The Importance Of Vocabulary In Language Learning And How To Be taught by Mofareh Alqahtani, 2015.

Nagy, W.E \& Anderson, R.C (1984). How many words are there in printed school English? Readingm Research Quarterly, 19, 304-330, in Research On Vocabulary Instruction In The Content Areas : Implication For Struggling Readers by Janis M. Harmon, 2005

Nagy, W. (1995). On the role of context in first- and second-language vocabulary learning.Technical report. No.627. Center for the study of reading, Urbana, IL.in The Use of Dictionary and Contextual Guessing Strategies for Vocabulary Learning by Advanced English-Language Learners by Shufen Huang1 \& Zohreh Eslami2

Nation, I. S. P. (2001). Learning vocabulary in another language. Cambridge: Cambridge University Press in The Importance of Vocabulary In Language Learning And How To Be taught by Mofareh Alqahtani, 2015; and in The Use of Dictionary And Contextual Guessing Strategies or Vocabulary Learning by Advanced English Language learners by Shufen Huang \& Zohreh Eslami, 2013, English language and Literature Studies; Vol.3, No.3; 2013

Nation, I. S. P. (2001). Learning vocabulary in another language. Cambridge: Cambridge University Press, in The Importance Of Vocabulary In Language Learning And How To Be taught by Mofareh Alqahtani, 2015 
Neuman, S. B., \& Dwyer, J. (2009). Missing in action: Vocabulary instruction in pre-k. The Reading Teacher, 62(5), 384-392. In The Importance of Vocabulary in Language Learning And How To Be Taught, by Mofareh Alqahtani, 2015, International Journal Of Teaching And Education.

Piaget, Jean (1976). To understand is to invent: The future of the education. New York : Penguin Books, in The Importance Of Vocabulary In Language Learning And How To Be taught by Mofareh Alqahtani , 2015.

Qian, D. (2004). Second language lexical inferencing: preferences, perceptions, andpractices.In P.Bogaards, \& B. Laufer (Eds.), Vocabulary in a second language: selection, acquisition, and testing (pp. 155-169). Philadelphia: John Benjamins Publishing Company, in The Use of Dictionary and Contextual Guessing Strategies for Vocabulary Learning by Advanced English-Language Learners by Shufen Huang1 \& Zohreh Eslami2

Read, J. (2000). Assessing vocabulary. United Kingdom: Cambridge University Press in The Importance Of Vocabulary In Language Learning And How To Be taught by Mofareh Alqahtani, 2015.

Rapaport, William J, 2004, What is the context for Contextual Vocabulary Acquisition; rapaport@cse.buffalo.edu. Department of Computer Science \& Engineering, Department of Philosophy, Center for Cognitive Science State University of New York at Buffalo, Buffalo, NY 14260-2000, USA http://www.cse.buffalo.edu/ rapaport/cva.html

Schmitt, N. (2000). Vocabulary in language teaching. Cambridge: Cambridge University Press, in The Importance Of Vocabulary In Language Learning And How To Be taught by Mofareh Alqahtani, 20015.

Teller, Marion. (2008). The effect of gestures on second language memorisation by young children. Gesture, John Benjamins Publishing, 8 (2), pp.219235.<hal-00375251>, in The Importance Of Vocabulary In Language Learning And How To Be taught by Mofareh Alqahtani, 20015. 